\title{
水彩パース図風レンダリング法
}

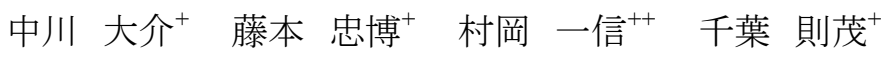 \\ +岩手大学工学部 ${ }^{++}$東北工業大学
}

naka@cis.iwate-u.ac.jp fujimoto@cis.iwate-u.ac.jp muraoka@tohtech.ac.jp nchiba@cis.iwate-u.ac.jp

本論文では, 建築等の完成イメージ図などに用いられるパース図を取り上げ, 3次元幾何モデルから 水彩パース図風画像を自動生成する手法について提案する. 本手法は, 水彩パース図の特徵である, 輪郭が描画される, 建物については彩色のはみ出しが無い, 樹木などの建物以外の対象は簡略化され て描かれることが多い, 淡い色彩が用いられることが多い, などの点を考慮したアルゴリズムの構成となっ ている.

\section{Watercolor-Style Rendering of Perspective Drawings}

Daisuke Nakagawa $^{+}$, Tadahiro Fujimoto ${ }^{+}$, Kazunobu Muraoka ${ }^{++}$and Norishige Chiba ${ }^{+}$

${ }^{+}$Iwate University, Faculty of Engineering, ${ }^{++}$Tohoku Institute of Technology

We propose a method for automatically generating watercolor-style perspective drawings from three-dimensional geometric models. The method would be useful in the architectural-design area. It employs several technical approaches that realize the following general features of real watercolor-style perspective drawings: the outlines and edges of objects are drawn, there is no overflow of watercolor in the coloring especially of buildings, another objects like botanical trees are rendered often in simplified drawing styles and transparent light colors are used in most cases.

キーワード: ハンフトリアリスティックレンダリング, 水彩画, パース

Keyword: non-photorealistic rendering, watercolor, perspective drawings

\section{1. はじめに}

近年, コンピュータグラフイックス $(\mathrm{CG})$ において 非写実的なレンダリング法の研究が盛んに行わ

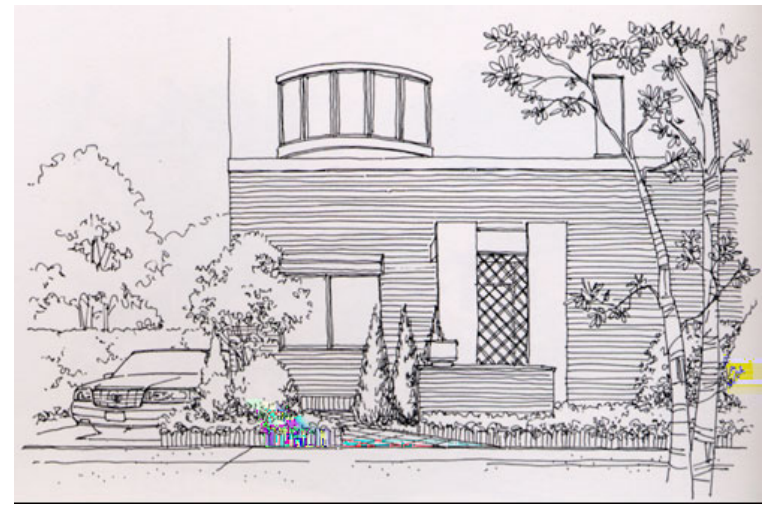

れている[1-21]が, 水彩パース図に注目したもの は少ない. 本報告では水彩パース図風画像を 3 次元幾何モデルから自動的に生成する手法を提

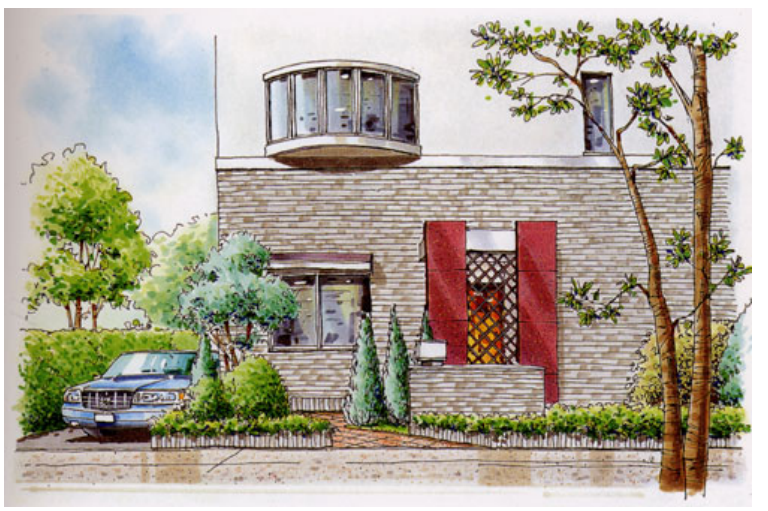

図1 実際のパース図[22] 
案する.

これまで提案されている非写実的なレンダリン グ法に関する研究としては, ペン画[1-8], 油絵 [9-11], パステル画[12], 水彩画[9,13]調画像を得 る手法について良く研究されてきている. また, こ れらの絵画調画像を得るアプローチとしては, 写 真などの2次元画像をベースとして絵画調画像に 変換する手法 $[1,10,14,15]$ と, 3次元幾何モデルを レンダリングして生成された3次元画像から絵画 調画像を生成するという3次元CGとしてのレンダリ ング法[2-9,12,16-21]がある. さらに, 手描きツール を提供するための筆と顔料(pigment)の振る舞い を模擬する手法に関する研究 $[12,13]$, 筆などのス トロークの生成に関する研究[10-12]などがある.

本研究の手法は, 3 次元画像から生成寸るもの である. 建築等の建設分野においては, 通常の3 次元 CGによる写実的なレンダリングが可能な現 在においても, 完成予想図として水彩パース図が 好んで用いられており，このようなパース図が CAD データから自動的に得られるような技術が開 発されれば非常に有用であると言える.

多くの水彩パース図では, 対象物の輪郭線が ペン等で描画され，その後彩色が施されている (図1参照)。輪郭線は対象物を鮮明にするため に, 特に建築物については直線で描かれることが 多く, 彩色は暖かみのある印象を与えるため, 一 般に淡い色で, 特に建築物については筆の跡が 目立たないように施されることが多い[22].また， 輪郭をはみ出した彩色が行われることは僅少であ る.この点において, 絵の具のにじみの効果や筆 の線を活かした通常の手描き風水彩画[13] とは異 なる特徴をもつ(ただし, 文献[13]で提案されてい る水彩の発色計算法はパース図においても有効 である）。一方，手描き風パース図の製作を支援 する実用的なソフトウェアとして Piranesi[23]などが あるが，3次元幾何モデルから水彩パース図風画 像を自動生成するものではない.

本論文では, 3次元幾何モデルから水彩パー 又図風画像を生成する手法を提案する. 本手法 では, 水彩パース図の特徵を踏まえ, 輪郭線描画 と彩色の2段階で画像生成を行う.輪郭線は，3 次元幾何モデルにレイトレーシング法をベースと した隠面消去法を適用し, ピクセル毎の可視面の 奥行き值 (Z值), 法線ベクトル, およびサーフェイ ス情報から輪郭を構成するピクセルを求めること
により定め, それをペン画風に描画する. 同一物 体の表面を構成するポリゴンの集合をサーフェイ スと呼び, 他のサーフェイスとはIDによって区別さ れる. 彩色のためには, まず, 紙を表す画像を用 意し，その上にRGB值と不透明度 $(0 \sim 1)$ を持つ レイヤを重衫る。 その際, 初期值として, RGB值 には通常のシェーディングモデルにより写実的に レンダリングしたCG画像を登録し, 不透明度には O (完全透明)を登録しておく. そして,このレイヤ 上で, 不透明度を向上させる筆を物体形状に応 じた（後述するように, 本手法では輝度值のみ考 慮した) ストロークに沿って走査させることにより， そのCG画像を浮き上がらせるといらアプローチで 彩色を行う。一般に, 自動的な描画法では筆のコ ントロール, 特に輪郭からの色のはみ出しを制御 することは非常に難しいため, 本手法では筆によ る色のはみ出しが起こらないアプローチを採用し た.

また, 水彩パース図では樹木などの添景や遠 方の対象は簡略化して描かれることが多いため, 本手法では, Z值の大きい輪郭線を簡略化する, 下絵とする3次元 CG画像にはZ值に応じた強さ で平滑化を施す，また色彩をZ值に応じて変化さ せるなどのアプローチも用いている.

\section{2. 建築物のレンダリング法}

本手法では建築物のレンダリングは 2 つのステ ップで行う.

まず, 幾何モデル (図2(a)参照)にレイトレーシ ング法を適用し, サーフェイス, $\mathrm{Z}$ 值, 法線ベクト ルの情報から輪郭線を描画する(図2(b)参照)． 次に, 紙を表す画像を用意し, RGB值と不透明 度 $(0 \sim 1)$ を持つレイヤを重ね, RGB值として通 常のシェーディングモデルにより写実的にレンダリ ングしたCG画像を登録し，不透明度しして0（完 全透明)を初期設定する.このレイヤ上で, 不透 明度を向上させる筆を物体形状に応じたストロー クに沿って走查させる(図2(c)参照)ことにより, CG 画像を浮き上がらせる(図2(d)参照).

\section{1 輪郭線の描画 \\ 2. 1.1 基本手法}

輪郭線の描画は, 幾何モデルをレイトレーシン グ法によってレンダリングしながら, 次の3つの条 件 


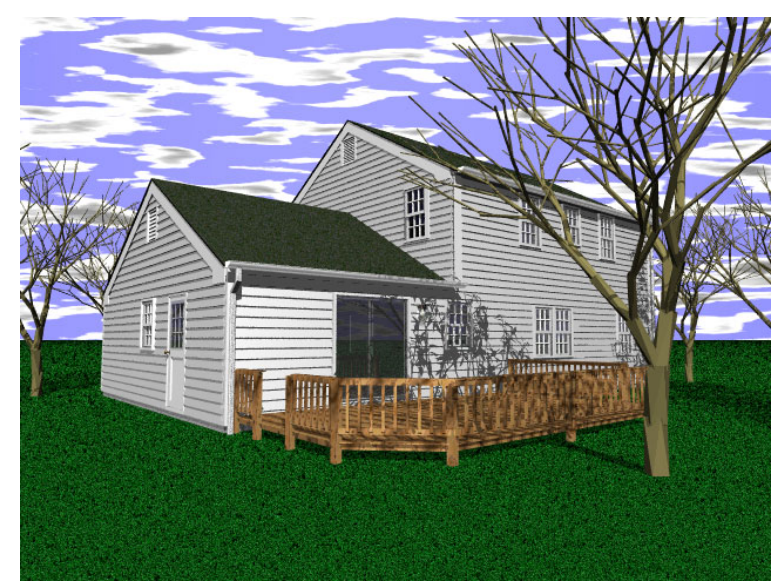

(a)シェーディング画像

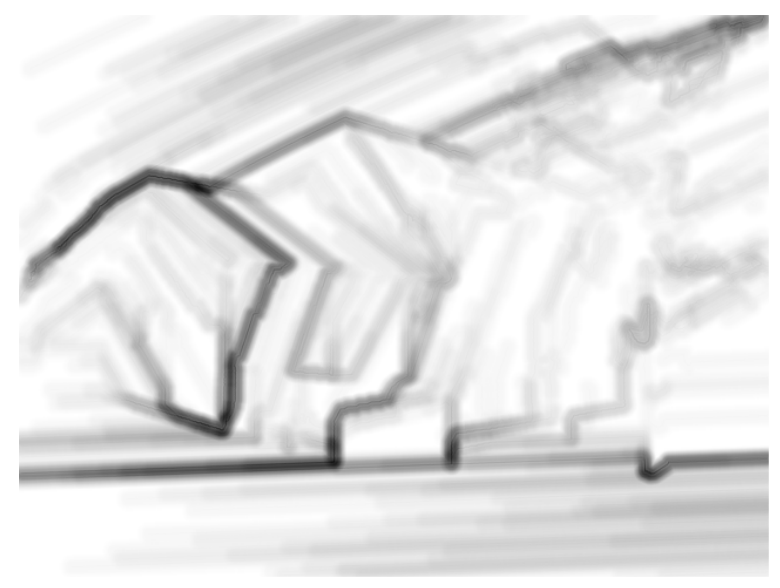

(c)筆跡

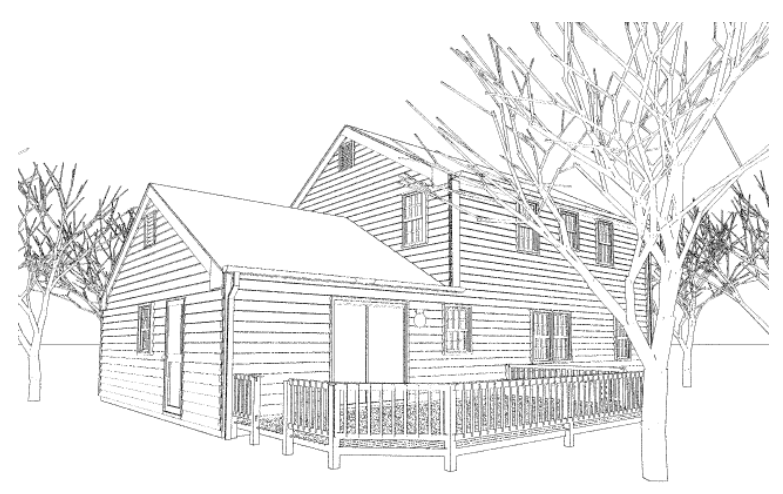

(b)輪郭線の描画

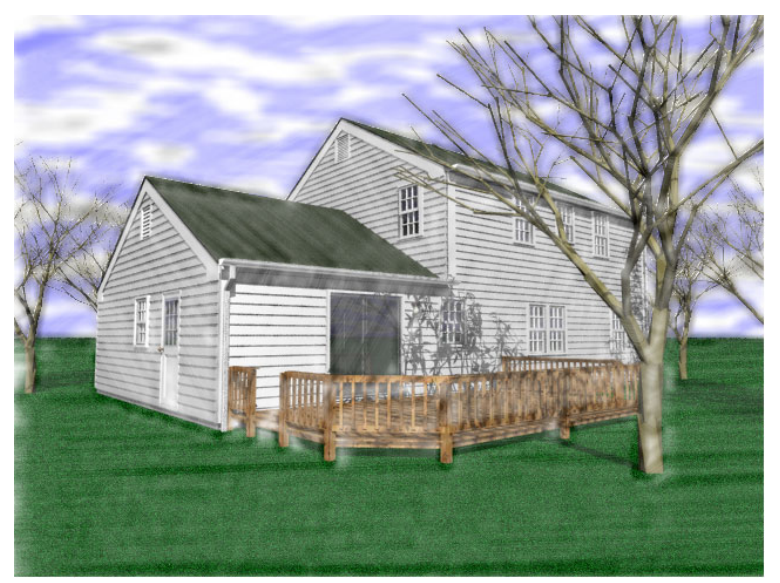

(d)彩色処理により得られた画像

図2 本アルゴリズムの処理の流れ

・隣り合うピクセルの法線ベクトルのなす角が閾 值以上である

・隣り合うピクセルの Z 值の差が閾值以上である

・隣り合うピクセルのサーフェイスが異なる

のうちいずれかを満足するピクセルを検出し，そ れを輪郭線ピクセルとして登録する。

1番目の条件における閾值 (angle) は以下の式で 求められる.

angle $=$ smooth + zweight $\cdot(180-$ smooth $)(1)$

$$
\text { zweight }=\left\{\begin{array}{lr}
0 & (\text { zbuffer }(x, y)<\text { zmin }) \\
\text { zbuffer }(x, y)-\text { zmin } & \text { zmax }- \text { zmin } \\
& (\text { zmin } \leq \text { zbuffer }(x, y) \leq \text { zmax }) \\
1 & (\text { zbuffer }(x, y)>\text { zmax })
\end{array}\right.
$$

ここで, smooth は輪郭線を抽出する基本と なる角度を調整するパラメタ, zbuffer $(x, y)$ はピ
クセル $(x, y)$ の Z值, zmin, zmax はそれぞれ Z值 による輪郭線の簡略化の効果 (遠い物体ほど輪 郭線が省略される) を調整するパラメタでデフ オルトは Z值の最小值と最大值である。なお, zmin,zmax は zmin<zmax を条件にユーザが任意 に設定することもできる.

2 番目の条件における閾值 $(z t h)$ は次式で求 められる。

$$
z t h=z f+z \text { weight } \cdot(z b-z f)
$$

ここで, $z f, z b$ は輪郭線抽出を調整するため のパラメタで，それぞれ，最も手前に位置する 物体, 最も遠くに位置する物体に対する閾值で ある。

図 3 に smooth を変えた場合の輪郭線描画の 例を示す。また，図 4 に Z 值による輪郭線の 簡略化の効果を示す. 


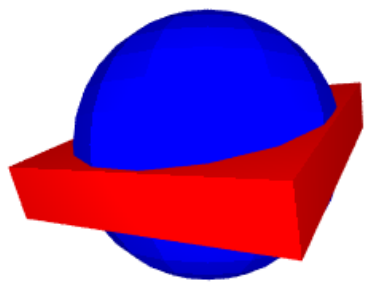

(a)シェーディング画像

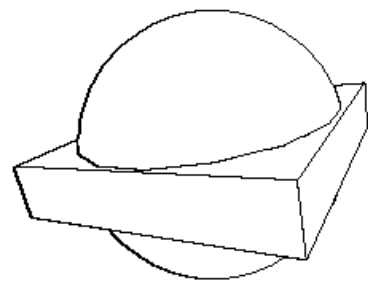

(b)輪郭線 $(s m o o t h=30)$

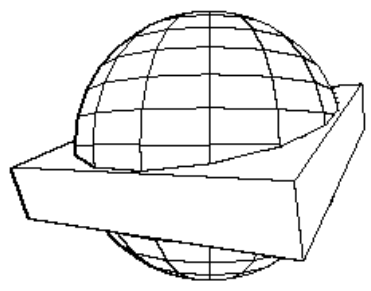

(c)輪郭線 $(s m o o t h=10)$ 図3 輪郭線の例

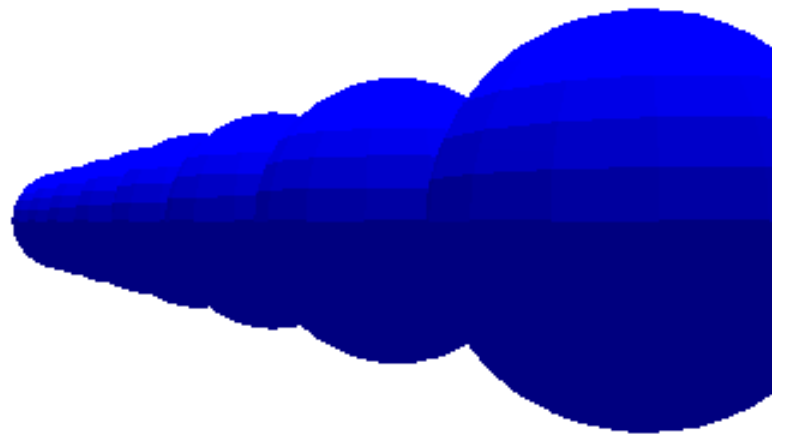

(a)シェーディング画像

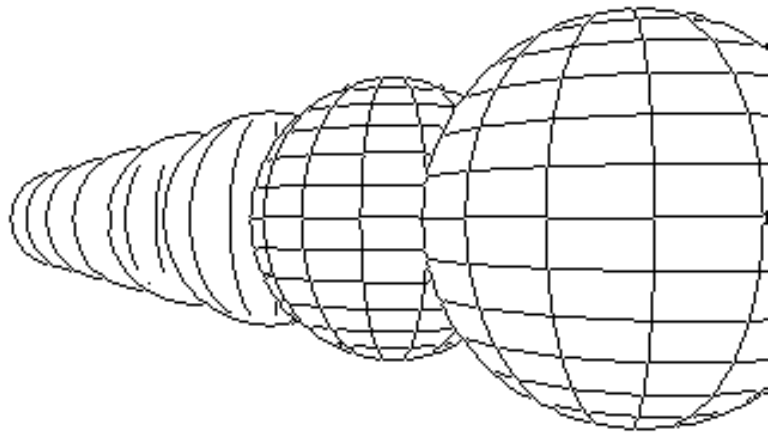

(b)Z 值による輪郭線の簡略化の効果

図 4 輪郭線の簡略化

\section{1.2 スーパーサンプリングを適用した手法}

2.1.1による手法では, 複雑な幾何モデルを 用いた場合，エイリアシングが発生する(図5(a)(b) 参照).これを解決するために, 1 つのピクセルを 格子状に細分割し，それぞれの格子点を仮想ピ クセルとしてレイを放射しスーパーサンプリングを 行うことによりアンタイエイリアシングされた輪郭線 を求める. ピクセルを $4 \times 4$ 格子に分けて 16 点に サンプリングした例を図5(c)(d)に示す. 図5(a)(b) の解像度は $640 \times 480$ pixels である.

\section{2 彩色処理}

一般に水彩画では対象物の等濃度方向に沿 って筆を走らせ彩色する. さらに, 長いストローク で描く時は太い筆を使う. 本アルゴリズムではこれ らを考慮して, ストロークは光源ベクトルと法線ベ クトルの外積の方向に走らせ, 筆跡の幅は検出し たストロークの長さに比例させる. ただし, 筆跡の 幅には有効範囲 (最小幅から最大幅まで)を設け， 長いストロークでも最大幅以上には広くせず, 最
小幅より短くなるストロークは描かないようにしてい る.この手法によって, 長く太い筆ストロークが優 先的に描かれる(図2(c)参照).

前処理として, レンダリング画像と紙を表現する ための画像を用意する.レンダリング画像はレイト レーシング法により輪郭線情報を検出する際に同 時に生成する. この画像の各ピクセルはRGB值と 不透明度 $(\mathrm{O}: 0 \sim 1)$ を持ち, 不透明度の初期值は $\mathrm{O}$ (完全透明)とする. 彩色処理アルゴリズムは以 下のようである.

ステップ1. 紙の画像を下層, レンダリング画像を 上層のレイヤとして配置する.

ステップ2． 筆跡の最小幅 $B$ に上限最小幅 $B_{\text {max }}$ の初期值を決める. 今回は $B_{\max }=20$ ピクセル幅 とした.

ステップ3．筆ストロークの開始点の候補となるピ クセルについて, 以下のステップ 3-1〜3-3 を 行う. その候補ピクセルとして, 最初は, 画像 の縦サイズメ横サイズ個のピクセルをランダム 


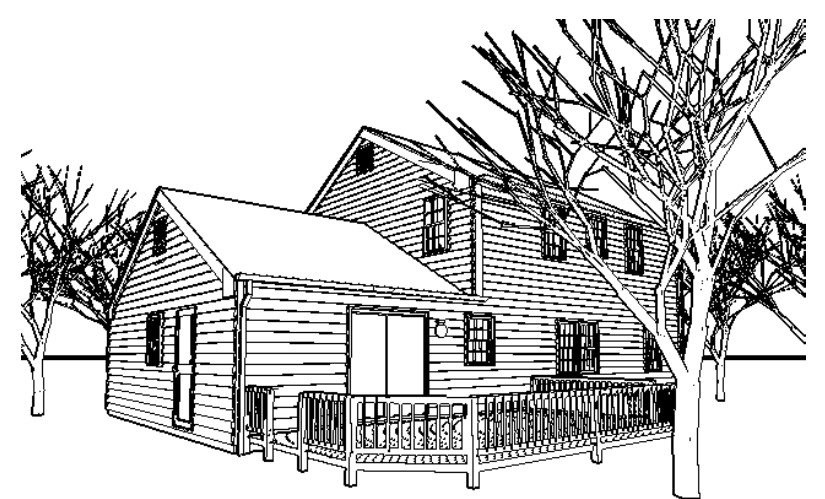

(a)基本手法

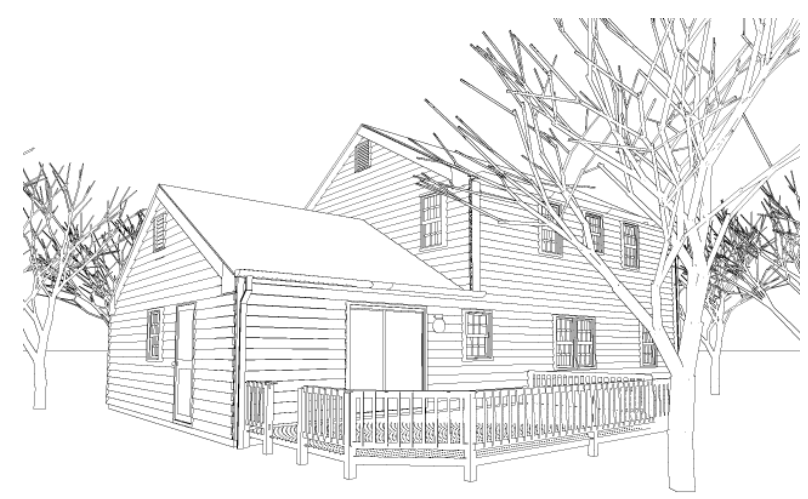

(c)スーパーサンプリング

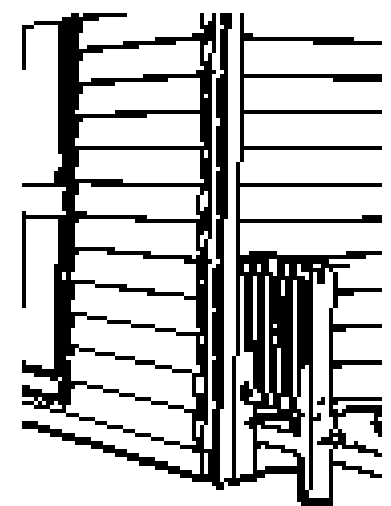

(b)基本手法 (拡大)

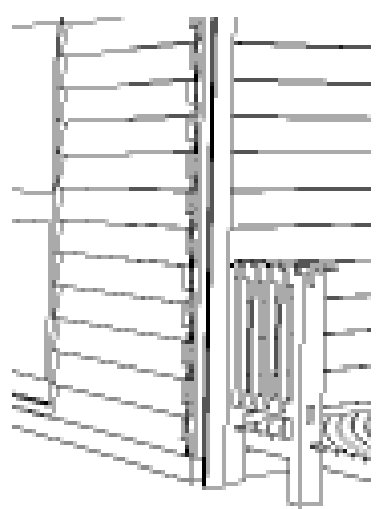

(d)スーパーサンプリング(拡大)

図5 複雑なモデルの輪郭線検出

に選び, その後, 画像の左上のピクセルから 走査線順に選んでいく.

ステップ3-1. 物体を構成するピクセルが見つかっ

た場合，これを開始点として，筆ストローク を生成する(後述).

ステップ3-2. ステップ 3-1 で生成した筆ストローク から筆跡の幅を求める (後述).

ステップ3-3. ステップ 3-2 で求めた筆跡の幅が最 小幅Bより大きな場合, 筆ストロークの周囲 部分の不透明度を増加させる(後述) (図6 参照).

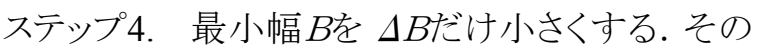
新たな最小幅 $\mathrm{B}$ 下゙限最小幅 $B_{\min }$ 以上である 場合にはステップ3に戻り, $B_{\min }$ より小さくなっ た場合にはステップ5に進む. なお, 今回は, $\Delta B=1$ ピクセル幅, $B_{\text {min }}=5$ ピクセル幅とし た.
ステップ5. 紙 $(\mathrm{Pa})$ とレンダリング画像 $\left(I_{\text {rend }}\right)$ のレ イヤを, 上記で求めた不透明度 $(\mathrm{O})$ によって次 式で合成し, 彩色画像 $(I)$ を得る.

$$
I=I_{\text {rend }} O+P a(1-O)
$$

ここで, 彩色処理アルゴリズムについて補足す る.

ステップ 3 の補足: 筆ストロークの開始点をラン ダムな候補ピクセルのみから選ぼうとすると, 画像 全体を覆うのに処理時間がかかってしまうため， 一定個数のピクセルをランダムに選んだ後, 左上 端から画像をスキャンするといら手法を用いた。

ステップ 3-1の補足:筆のストロークの生成は以 下の手順で行う.

(1) 物体を構成するピクセルが見つかった点をス トロークの開始点とする.

(2) 開始点に筆ストロークの先端を置き, 次の 


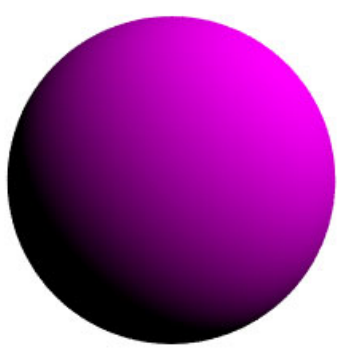

(a)シェーディング画像

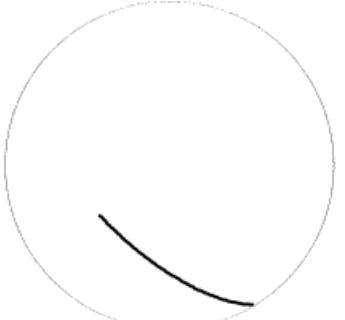

(b)ストローク (c)筆跡

\section{図 6 筆跡の生成}

(2-1),(2-2)を繰り返すことで, ストロークの終了 点まで先端の位置を更新していく.

（2-1） 先端の光源ベクトル L と物体の法線ベクト ル $\mathrm{N}$ との外積を求める. このベクトルをス クリーンに投影したベクトルを正規化しそ の先端を, 筆ストロークの新しい先端とす る.

（2-2） 筆ストロークの先端が，次の何れかの場 合, その直前までの先端を筆ストロークの 終点とする.

・ 物体の無い領域にある.

・ スクリーンの外にある。

・ 先端位置の不透明度が閾值より高い. なお, 閾值(threshold)は以下の式で求め る.

$$
\text { threshold }=\text { base }+\left(1.0-p\left(I_{\text {rend }}\right)\right) \cdot \text { cont }
$$

ここで, base と cont は輝度值とコントラ ストを調整するパラメタ, $p(x)$ は RGB 值 $x$ について NTSC 加重平均法により, 輝度 值を返す関数である. cont の值を上げる と, レンダリング画像上の輝度值の低い (暗い)ところをよりこすり出す効果が得ら れる.

（3）開始点から終了点までのベクトルの集合を筆 ストロークとする.

なお, 手描き風の印象を与えるため, 上の手順 で得られた筆ストロークにノイズを付加する.

ステップ 3-2 の補足:筆跡の幅はストロークの長 さの $\times 0.3$ とする. ただし, 筆跡の最小幅 $B$ の上限 最小幅 $B_{\max }$ より大きい場合はその筆跡の幅を $B_{\max }$ とする.

ステップ 3-3の補足: 不透明度の増加量はストロ

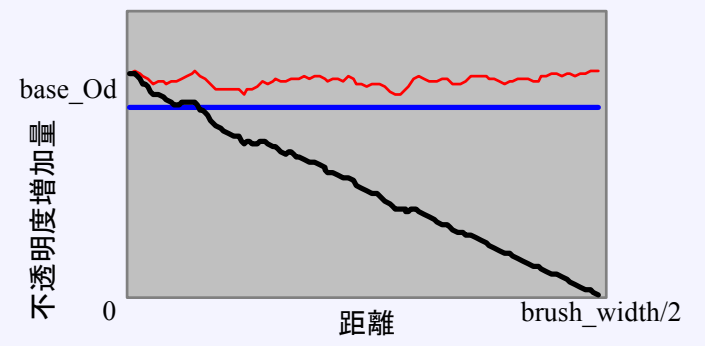

図7 距離と不透明度増加量

ークと各ピクセルの最短距離によって定める. 距 離と増加量との関係は, 筆の不均一性を表現す るためにノイズを入れ，ここでは図7のグラフで示 すような不透明度を用いた. 図で, 青の線が基本 的な不透明度のグラフで, それにノイズを加えた のが赤の線である.この不透明度は，

$$
\text { base_Od } \cdot(1.0+c \cdot \text { random }) \cdot\left(1.0-\frac{x}{\frac{\text { brush_width }}{2}}\right)
$$

で定めている.ここで, base_Od は基本的な不透 明度の大きさであり(図では青の線), $c \cdot$ random は加えたノイズ成分 (加えた結果は赤の線),

$(1.0-x /($ brush_width/2)) は，筆跡の幅（大きさ はbrush_width)方向に, ㅈトロークからの距離 $x$ に 忘じて線形に減衰させるための係数であり, 結果 の不透明度は黒の線で表される. なお, パース図 では筆跡を目立たせないように彩色することが多 いので,ここでは筆の両端での筆跡を目立たなく するために減衰させている. どのような減衰が良 好な効果を生むかに関する詳細な検討は今後の 課題である. また, random には, 值の範囲が $(0.0$ 〜1.0)であるような一様乱数列を移動平均法で平 滑化したものを用いた. なお, 今回は $c=0.25$, base_Od $=0.08$ とした. 


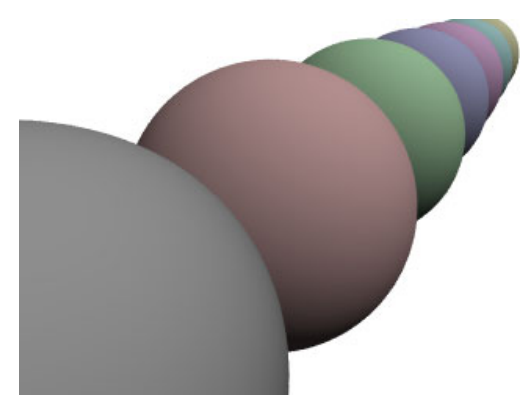

(a)シェーディング画像

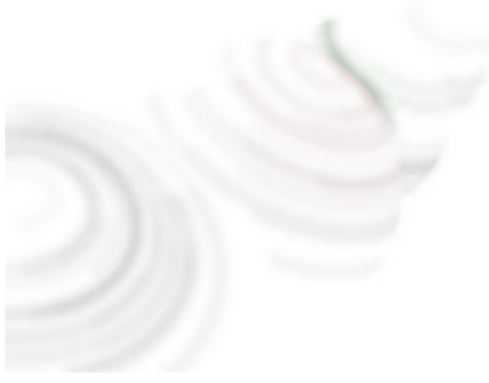

(b)筆ストローク $=60$ 本

図8 彩色の例

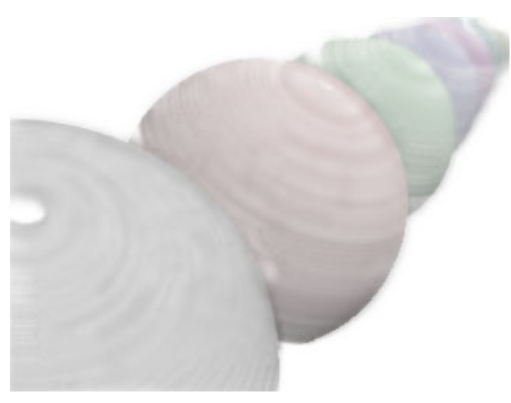

(c)筆ストローク $=766$ 本

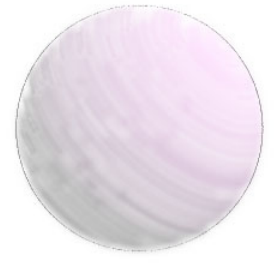

(a) base $=0.1$, cont $=0.1$

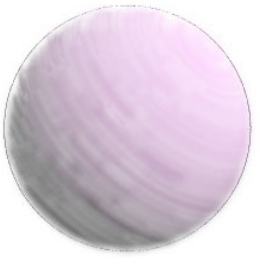

(b) base $=0.1$, cont $=0.3$

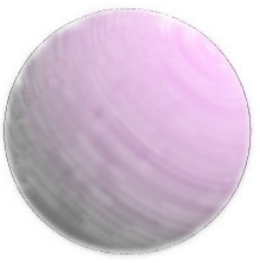

(e) base $=0.3$, cont $=0.1$

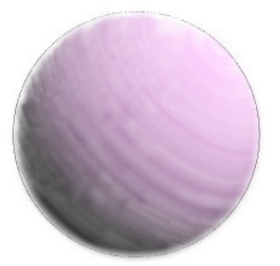

(c) base $=0.1$, cont $=0.5$

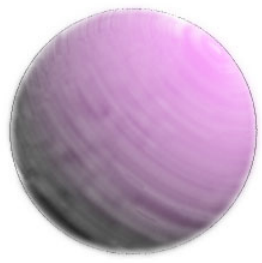

(f) base $=0.5$, cont $=0.1$

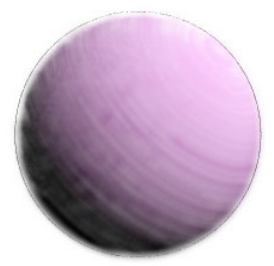

(d) base $=0.1$, cont $=0.7$

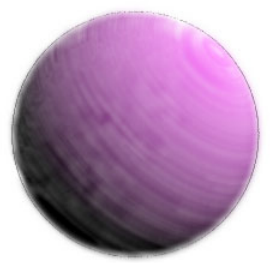

(g)base $=0.7$, cont $=0.1$

図 9 不透明度の閾值のパラメタ変更による効果

本手法では，画像にZ值に応じて平滑化処理 を施す. 平滑化は, ピクセル $(x, y)$ を心とした, 一辺の長さが $\operatorname{reach}(x, \mathrm{y})$ の正方形内部のピクセ ル值の平均值を, ピクセル $(x, y)$ の新しいピクセ ル值とすることにより行う。

$$
\operatorname{reach}(x, y)=\text { zweight } \cdot \text { range }
$$

ここで, rangeは平滑化の範囲を調整するた めのパラメタである。 zweightには(2)式を用 いた。

図8に実際のモデルへの適用した例を示す。 画像解像度は全て $320 \times 240$ pixels である. (a)は 通常のレンダリング画像. (b)は彩色処理中の画 像で, 筆ストロークが 60 本のものである. 等濃度 の方向に筆が走っているのがわかる. (c)は処理 後の画像で, 筆ストロークは 766 本である. 図9に (5)式中の base と cont の值を変えた例を示す. 入 力モデルには図6(a)を用いた. 画像解像度は全 て $320 \times 240$ pixels である. cont の值を上げる事で,
レンダリング画像上の輝度值の低い(暗い)ところ をよりこすり出す効果が得られている.

水彩パース図では遠くの物体ほど形も色も 簡略化されて描かれるが, 本手法では Z 值に応 じた平滑化処理で色の簡略化を簡便に表現し ている.なお，これによって境界でわずかに色 が混じりあい, 色がはみ出ているように見える 場合もあるが, 輪郭線が描かれることで目立た なくなる.また, 視点に近い物体ほど色の混じ り方は少なく, 輪郭線も描かれ易いため, 実用 上は問題ないと思われる.

\section{3. 樹木のレンダリング法}

一般的にパース図では対象物が樹木の場合, 葉などには輪郭線を加えずに簡略化して描かれ る.このため, 本手法では, 葉のみをレンダリング した画像 (Leaf レイヤ)を生成し, 葉以外のオブジ エクトを2節による手法で描画した画像に $\alpha$ ブレン ディングすることで, これを実現する. 
樹木の描画では, 近くの葉を鮮明に描き, 遠く の葉をぼかす，という描き方をすることが多い，そ こで, まず, Leaf レイヤに対して以下の手順で視 点からの距離に応じた平滑化を行ない, その後, メ゙レンディングを行う.

(1) Leaf レイヤの全ピクセルをスキャンし, 葉では ないピクセルの不透明度 $(\mathrm{O})$ と RGB 值をOに し, 葉を構成するピクセル $\left(x_{i}, y_{i}\right)$ の不透明度 $O\left(x_{i}, y_{i}\right)$ を 1.0-frange にする. なお, frange は (11)式で決定する.

(2) Leaf レイヤの全ピクセルを再びスキャン し，葉を構成する全ピクセルを探索する. 葉を構成するピクセル $\left(x_{i}, y_{i}\right)$ が見つかった 場合，そのピクセルの周囲のピクセルに対 して，葉の不透明度および RGB 值をピク セル間の距離と Z 值に応じて拡散させる ため, Leaf レイヤ上の全ピクセル $\left(x_{j}, y_{j}\right)$ について以下の処理を行う.

(2-1) 式(8)により, 不透明度Odの值を計算する. この值がピクセル $\left(x_{j}, y_{j}\right)$ の不透明度より大き ければ, この值をピクセル $\left(x_{j}, y_{j}\right)$ の不透明 度とする。

$O d=$ Densiy $($ distance $) \cdot O\left(x_{i}, y_{i}\right)$

ここで，

$$
\begin{aligned}
\text { distance } & =\sqrt{\left(x_{i}-x_{j}\right)^{2}+\left(y_{i}-y_{j}\right)^{2}} \\
\text { Density }(d) & = \begin{cases}e^{-(d-\text { flat })^{2} / \text { frange }} & (d \geq \text { flat }) \\
1 & (d<\text { flat })\end{cases}
\end{aligned}
$$

$$
\text { frange }=\frac{\text { zbuffer }\left(x_{i}, y_{i}\right)-\text { ozmi }}{\text { ozma }- \text { ozmi }}
$$

ozmi,ozma はZ值に応じた拡散を調整する パラメタである.これらのデフォルト值は葉 オブジェクトのZ值の最小值と最大值である が, ozmi<ozma を条件にユーザが任意に設 定することもできる. 式(10)中の flat $(\geqq 0)$ は 拡散のしかたを調整するパラメタである.こ れにより, 関数 Density はd<flat の範囲でフ ラットな部分を持つ. その結果, 葉を構成す るピクセル $\left(x_{i}, y_{i}\right)$ の近傍のピクセル $\left(x_{j}, y_{j}\right)$ では, 不透明度が急に減少することなく, ピクセル $\left(x_{i}, y_{i}\right)$ の不透明度 $O\left(x_{i}, y_{i}\right)$ が与えられる.これ
は, flat の值を調整することで, 異なる筆の 太さによるぼかしの効果を生み出す.

(2-2) Leaf レイヤのピクセル $\left(x_{j}, y_{j}\right)$ の不透明度 $O\left(x_{j}, y_{j}\right)$ が Densiy (distance) より小さけれ ばピクセル $\left(x_{j}, y_{j}\right)$ の RGB 值を葉を構成す るピクセル $\left(x_{i}, y_{i}\right)$ の RGB 值で置き換える.

本手法では, 関数 Density とfrange によって, 遠くの葉ほど大きく薄く描かれるようにしている. ま た, flat を大きくすると葉は大きく描かれるようにな る.

一般に, 水彩パース図では樹木の葉などは淡 い色で描かれる事が多い. 本手法では Leaf レイ ヤに淡い色を持つレイヤ $(\mathrm{RGBO}(1.0,1.0,0.4,0.3)$ )をブレンドしてから処理を施した. 図 10 に生成画 像を示寸. 画像解像度は全て $480 \times 320$ pixels で ある。

\section{4. 画像生成結果}

本手法による画像生成例を図 11 に示寸. 画像 解像度は全て $640 \times 480$ pixels である. (a)は通常 のレンダリングを行った画像であり，(b)は本手法 により輪郭線と彩色のシミュレーションを行った画 像である. (c)は紙の画像で, (d)は(c)を下層レイヤ に設定して本アルゴリズムを適用した例である.

次章で述べるように今後の課題は多いものの, 生成例により, 本手法は水彩パース図の特徵であ る, 輪郭が描画される, 建物については彩色のは み出しが無い, 樹木などの建物以外の対象は簡 略化されて描かれる, 淡い色彩が用いられること が多い, 紙の色彩の影響を受ける, などが反映さ れた手法であることが確認できる.

計算には DOS/V Celeron-666 MHzを使用した。 図 11(d)の生成に要した時間をステップ毎に表 1 に示す.

表1 図 11(d)の生成時間

\begin{tabular}{|l|c|}
\hline \multicolumn{1}{|c|}{ 各処理 } & 生成時間 $(\mathrm{s})$ \\
\hline 前処理 & 13 \\
\hline レンダリング & 1502 \\
\hline 彩色処理 & 4548 \\
\hline 葉のレンダリング & 719 \\
\hline 葉レイヤの平滑化 & 757 \\
\hline 総時間 & 7539 \\
\hline
\end{tabular}




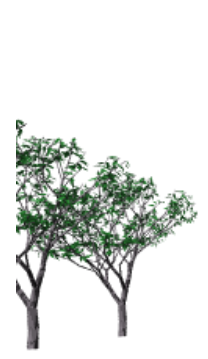

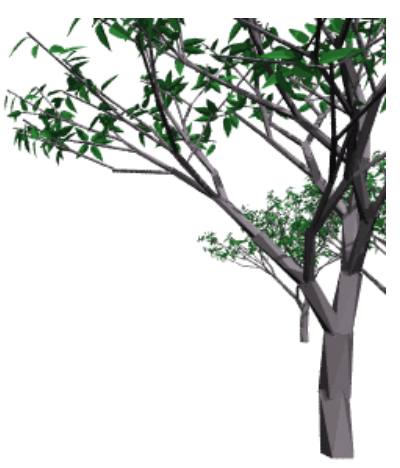

(a)シェーディング画像

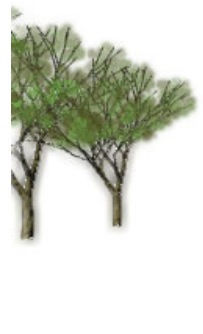

(b)生成画像

図 10 樹木の生成画像例

\section{5. おわりに}

本論文では3次元幾何モデルから水彩パース 図風画像を生成するための基本的な手法と, 水 彩画調パース図の特徵を踏まえた, 樹木などの 添景や遠方の対象を簡略化して描く手法につい て提案し, その効果を画像生成例により示した.

今後の課題としては, 以下のようなことがあげら れる.

(a) 特に彩色アルゴリズムの効率化を図る.

(b) 等輝度方向に求めているストロークの生成法 について, 物体の輪郭やテクスチャの方向 性を考慮できるようにする.

(c) 筆の不透明度増加量の望ましいグラフに関 する詳細検討を行う.

(d) ペンや筆の質感を向上させるための紙質等 を考慮したモデルへ拡張する.

(e) 実際の水彩パース図に見られるような, より 淡い色で彩色するための, 既定值の物体色 から水彩調の色彩へ自動変換する手法を開 発する。

(f) 絵の具の光学特性を考慮した発色について 検討する.

なお, 課題(b)については, 開発済の線描表現 法[1]におけるストロークの生成法を拡張して適 用することを検討している.

参考文献

[1]中川大介, 山口恵介, 藤本忠博, 村岡一信, 千葉則茂, 濃淡画像からペン画調画像への変 換法 一線描, 点描一, 画像電子学会誌, 2001,
Vol30, No4, pp.350-361.

[2]G.Winkenbach and D.H.Salesinl, Computer-G enerated Pen-and-Ink Illustration, SIGGRAP H’94, pp.91-100, 1994.

[3] L.Markosian, M.Kowalski, S.Trychin and J. Hughes, Real Time Non-Photorealistic Rend ering, SIGGRAPH'97, pp.415-420, 1997.

[4]M.P.Salisbury, M.T.Wong, J.F.Hughes, and D.H.Salesin, Orientable Textures for Image-B ased Pen-and-Ink Illustration, SIGGRAPH'97, pp.401-406, 1997.

[5]G.Winkenbench and D.H.Salesin, Rendering Parametric Surfaces in Pen and Ink, SIGGR APH'96, pp.469-476, 1996.

[6]J.Hamel, S.Schlechtweg and T.Strothotte. An Approach to Visualizing Transparency in Co mputer-Generated Line Drawings. Proceedings of Information Visualisation'98 , pp. 151-15 6, 1998.

[7]J.Hamel and T.Strothotte, Capturing and ReUsing Rendition Styles for Non-Photorealistic Rendering, EUROGRAPHICS '99, pp.C-17 3-C-182, 1999.

[8]G.Elber. Interactive Line Art Rendering of $\mathrm{F}$ reeform Surfaces, EUROGRAPHICS '99, pp. C-1-pp.C-12, 1999.

[9]B.J.Meier, Painterly rendering for animation. Holly Rushmeier, editor, SIGGRAPH'96, pp. 477-484, 1996.

[10]A.Hertzmann, Painterly rendering with curv ed brush strokes of multiple sizes, SIGGRAP H'98, pp.453-460, 1998. 


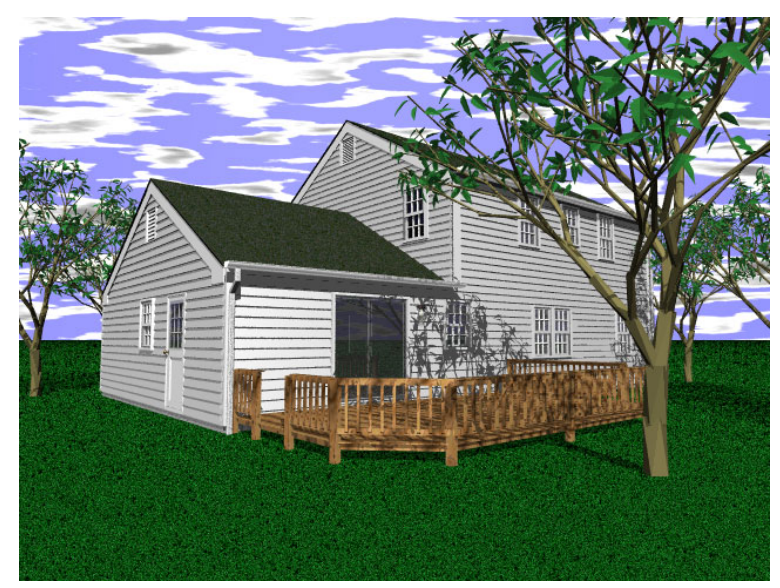

(a)シェーディング画像

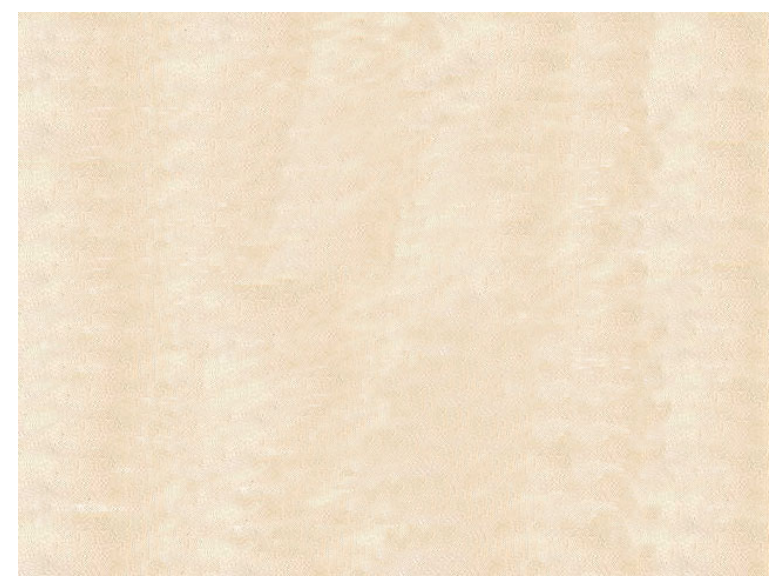

(c)紙画像

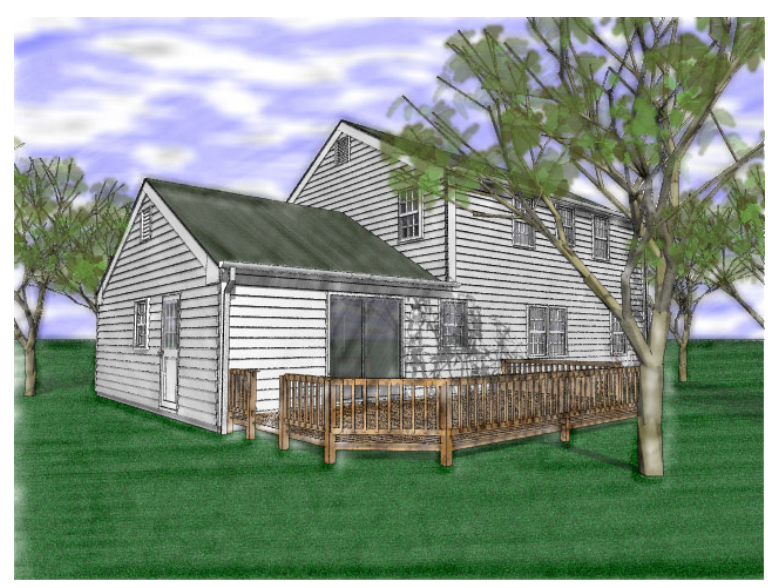

(b)生成画像

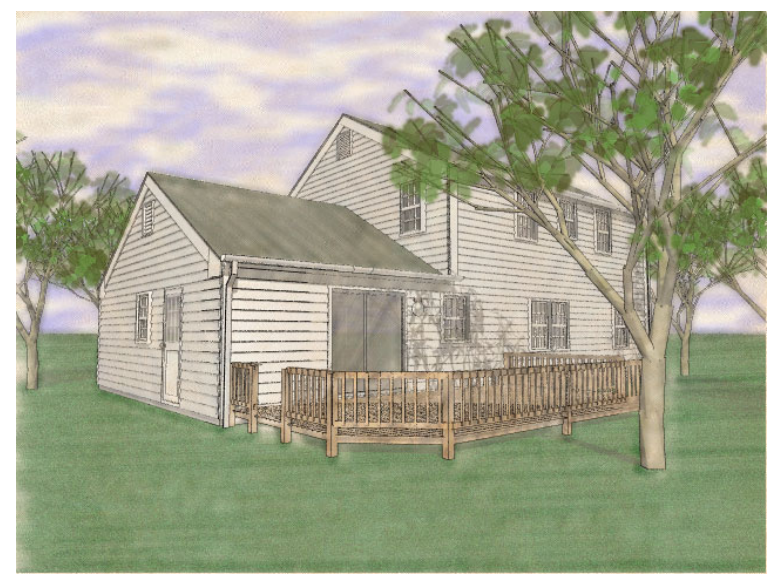

(d)生成画像

図 11 水彩画風パース図の生成例

[11]M.hiraishi and Y.Yamaguchi. Image $\mathrm{M}$ oment-Based Stroke Placement, SIGGR APH'99 Conference Abstracts and Appli cations, pp.247-248, 1999.

[12]村上 恭子, 鶴野 玲治, 顔料及び支持体の 特性を考慮したパステル画風レンダリング, 芸 術科学学会論文誌, vol.1, pp.89-96, 2002.

[13] C.J.Curtis, S.E.Anderson, K.W.Fleischer, a nd D.H.Salesin. Computer-Generated Watercol or, SIGGRAPH'97, pp.421 - 430, 1997.

[14]O.Verevka and J.W. Buchanan, Halftoning with Image-Based Dither Screens, GI'99, pp. 167-174, 1999.

[15]L.Streit and J.Buchanan, Importance Driven Halftoning, EUROGRAPHICS'98, pp.C-207C-217, 1998.

[16]J. D. Northrup and L.Markosian, Artistic si lhouettes: A hybrid approach. Non-photoreali stic Animation and Rendering. SIGGRAPH'0 0, pp.31-38, 2000.

[17]R.C.Zeleznik, K.P.Herndon and J.F.Hughes SKETCH: an interface for sketching 3D scen es, SIGGRAPH'96, pp. 163-70, 1996.

[18]L.Streit, O.Veryovka and J.Buchanan, Non -photorealistic Rendering Using an Adaptive Halftoning Technique, SKIGRAPH'99.[http:// www.cs.ubc.ca/spider/streit/papers/Skigraph99.p df]

[19]O.Veryovka and J.Buchanan, Comprehensi ve Halftoning of 3D Scenes, EUROGRAPH ICS'99, pp.C-14-C-22, 1999.

[20]O.Deussen, J.Hamel, A.Raab, S. Schlechtwe $\mathrm{g}$ and T.Strothotte, An illustration technique using hardware-based intersections and skelet ons, GI'99, pp.175-182, 1999.

[21]T.Saito and T.Takahashi, Comprehensible 
Rendering of 3-D Shapes, SIGGRAPH'90, pp.197-206, 1998.

[22]宮後浩, “緑のプレゼンテーション-GREEN P RESENTATION-", 学芸出版社, 2000.

[23]Priranesi [http://www.informatix.co.uk/pirane si/index.shtml] 